\title{
PENGETAHUAN IBU DAN PEMBERIAN ASI EKSKLUSIF DENGAN KEJADIAN STUNTING PADA BALITA 2-5 TAHUN DI PUSKESMAS KAWANGKOAN MINAHASA
}

\author{
${ }^{1}$ Grace K.L. Langi, ${ }^{2}$ I Made Djendra, ${ }^{3}$ Rudolf B. Purba, ${ }^{4}$ Ryan S. P. \\ Todanggene \\ ${ }^{1234}$ Jurusan Gizi Poltekes Kemenkes Manado \\ Email koresponden : kllge4245@gmail.com
}

\begin{abstract}
Nutrition is an important part of growth and development, because there is a connection and is related to health and intelligence, malnutrition. Stunting is a linear growth disorder that can affect the increased risk of illness, death, and impaired late motor development, and stunted mental growth. The type of this research is analytic observational with cross sectional study approach. The population in this study were all children under five in the work area of Kawangkoan Health Center in Minahasa Regency. Children under five 2-5 years. The respondent is mother. The number of samples of this study amounted to 41 people with a sampling technique that is using simple random sampling technique. The results of research on the level of maternal knowledge of 41 respondents were $39.0 \%$ who lacked knowledge, and $41.5 \%$ had sufficient knowledge, while $19.5 \%$ had good knowledge. the rate of exclusive breastfeeding is $41.5 \%$ which is less than exclusive breastfeeding, while $39.0 \%$ is good, $19.5 \%$ is enough to provide exclusive breastfeeding. Toddler respondents who have normal height category are $46 \%$, and category is very short, $31.7 \%$, while the short category is $22.0 \%$. kawangkoan health center.
\end{abstract}

Keywords: mother's knowledge, exclusive breastfeeding, stunting, toddlers 2-5 years.

\section{PENDAHULUAN}

Stunting merupakan gangguan pertumbuhan linier yang dapat memengaruhi meningkatnya terjadinya resiko kesakitan, kematian, dan gangguan perkembangan motorik terlambat, serta terhambatnya pertumbuhan mental. Stunting apabila terjadi pada masa golden periode perkembangan otak (0-3 tahun), maka berakibat pada perkembangan otak yang tidak baik.

WHO dan Unicef merekomendasikan 4 (empat) pola makan terbaik bagi anak sampai usia 2 tahun, yaitu Inisiasi Menyusui Dini (IMD) dalam 30 sampai 60 menit pertama setelah lahir, memberikan ASI eksklusif sampai bayi usia 6 bulan, mulai memberikan makanan pendamping mulai usia 6 bulan dan meneruskan pemberian ASI sampai anak berusia 2 tahun (WHO dan Unicef, 2012).

Peranan orang tua terutama ibu sangat penting dalam pemenuhan gizi anak karena anak membutuhkan perhatian dan dukungan orang tua dalam menghadapi pertumbuhan dan perkembangan yang sangat pesat. Mendapatkan gizi yang baik diperlukan pengetahuan gizi yang baik dari orang tua agar dapat menyediakan menu pilihan yang seimbang.

Tingkat pengetahuan gizi seseorang berpengaruh terhadap sikap dan perilaku dalam pemilihan makanan. Seorang ibu yang memiliki pengetahuan dan sikap gizi yang kurang akan sangat berpengaruh terhadap status gizi anaknya dan akan sukar untuk memilih makanan yang bergizi untuk anak dan keluarganya.

Pengetahuan gizi yang tidak memadai, kurangnya pengetahuan tentang kebiasaan makan yang baik,serta pengertian yang kurang tentang kontribusi gizi dari berbagai jenis makanan akan menimbulkan masalah kecerdasan dan 
produktivitas terutama pada balita atau dikenal juga dengan anak yang berusia antara 1-5 tahun ( Tasya Watania, Nelly Mayulu, Shirley E. S. Kawengian, 2016).

Kejadian balita stunting (pendek) merupakan masalah gizi utama yang dihadapi Indonesia. Berdasarkan data Pemantauan Status Gizi (PSG) selama tiga tahun terakhir pendek memiliki prevalensi tertinggi dibandingkan dengan masalah gizi lainnya seperti gizi kurang, kurus, pendek dan gemuk. Pravalensi balita pendek mengalami peningkatan dari tahun 2016 yaitu $27,55 \%$ menjadi $29,6 \%$ pada tahun 2017. Prevalensi balita pendek di Indonesia cenderung statis. Hasil Riset Kesehatan Dasar (Riskesdas) tahun 2007 menunjukkan pravalensi balita pendek di indonesia sebesar $36,8 \%$. Pada tahun 2010 , terjadi sedikit penurunan menjadi $35,6 \%$. Namun prevalensi balita pendek selanjutnya akan diperoleh dari hasil riskesdas tahun 2018 yang juga menjadi ukuran keberhasilan program yang sudah diupayakan oleh pemerintah (Jurnal Buletin-stunting 2018).

Stunting dapat menimbulkan dampak jangka pendek dan jangka panjang. Stunting merupakan salah satu target Sustainable Development Goals (SDGs) yang termasuk pada tujuan pembangunan berkelanjutan ke-2 yaitu menghilangkan kelaparan dan segala bentuk malnutrisi pada tahun2030 serta mencapai ketahanan pangan. Target yang ditetapkan adalah menurunkan angka stunting hingga $40 \%$ pada tahun 2025 (Didik Budijanto, 2016).

Data Riset Kesehatan Dasar (Riskesdas) 2013 menunjukkan prevalensi balita stunting di Indonesia mencapai 37\% (terdiri dari 18\% sangat pendek dan 19,2\% pendek) yang berarti terjadi peningkatan tahun 2010 (35.6\%) dan tahun 2007 $(36,8 \%)$ Provinsi Sulawesi Utara prevalensi stunting pada balita mencapai angka $31,4 \%$. Sedangkan data yang diperoleh dari Puskesmas Kawangkoan bahwa 70 balita diperkirakan kurang gizi (Profil Puskesmas Kawangkoan 2018). Berdasarkan prevalensi stunting tersebut, kejadian stunting di provensi sulawesi utara khususnya puskesmas kawangkoan termasuk masalah.(Riskesdas 2013).

Berdasarkan hasil uraian di atas maka peneliti tertarik untuk mengetahui hubungan pengetahuan ibu dan pemberian ASI eksklusif dengan kejadian stunting pada balita 2-5 tahun di wilayah kerja Puskesmas Kawangkoan Kabupaten Minahasa.

\section{METODE}

Penelitian ini merupakan penelitian observasional analitik dengan pendekatan cross sectional study (Notoadmodjo,2010). Penelitian ini dilaksanakan pada bulan Maret sampai April tahun 2019 dengan mengambil tempat di wilayah kerja Puskesmas Kawangkoan Kabupaten Minahasa. Populasi dalam penelitian ini adalah seluruh balita di wilayah kerja Puskesmas Kawangkoan Kabupaten Minahasa. Sampel adalah anak balita berusia 2-5 tahun. Jumlah sampel penelitian ini adalah 41 orang dengan menggunakan teknik random sampling. Instrumen atau alat pengumpul data yang digunakan dalam penelitian ini berupa kuesioner, antropometri TB/U.

Analisis univariat data dianalisis dengan menampilkan data dalam bentuk distribusi frekuensi yang dilaksanakan tiap-tiap variabel dari hasil penelitian yaitu variabel independen (pengetahuan ibu dan pemberian ASI eksklusif) dan variabel dependen (kejadian stunting).

Analisis bivariat bertujuan untuk mengetahui hubungan antara variabel independen dengan variabel dependen melalui uji chi square. Uji ini digunakan untuk melihat hubungan antara pengetahuan ibu dan pemberian ASI eksklusif dengan kejadian stunting, dengan tingkat kemaknaan $(\alpha=0,05)$. 
HASIL

Hasil penelitian ini tentang distribusi responden ibu menurut golongan umur menunjukkan bahwa paling banyak berumur 36-40 tahun sebanyak 17 ( $41.4 \%)$ responden, responden yang berumur 29-35 tahun sebanyak 8 (19.5\%) responden,responden yang berumur 24-28 tahun sebanyak 9 (21.9\%) dan responden penelitian yang paling sedikit berada pada golongan umur 41-51 tahun sebanyak $7(17.2 \%)$ responden.

Hasil distribusi responden anak menurut golongan umur, dimana responden penelitian paling banyak berumur 4-5 tahun sebanyak $15(36.6 \%)$ responden, responden yang berumur 2 tahun sebanyak 14 (34.1\%) responden dan responden penelitian yang paling sedikit berada pada golongan umur 3 tahun sebanyak 1 $(29.3 \%)$ responden.

Distribusi responden berdasarkan karakteristik jenis kelamin balita berdasarkan hasil analisis univariat karakteristik responden menurut jenis kelamin menjelaskan bahwa jenis kelamin laki-laki paling banyak menjadi responden penelitian, sebanyak $21(51.2 \%)$ responden, dan jenis kelamin perempuan paling sedikit sebanyak $20(48.8 \%)$ responden.

Berdasarkan hasil univariat karakteristik responden menurut status gizi balita menjelaskan bahwa balita berstatus gizi normal paling banyak $19(6.3 \%)$ responden,balita berstatus gizi sangat pendek sebanyak $13(31.7 \%)$ responden, dan balita berstatus gizi pendek $9(22 . \%)$ responden. Adapun, distribusi responden berdasarkan karakteristik tingkat pendidikan tingkat pendidikan berdasarkan hasil univariat menjelaskan bahwa tingkat pendidikan SMA paling banyak menjadi responden Penelitian, sebanyak $27(65.9 \%)$ responden, tingkat pendidikan S1 sebanyak $9(22.0 \%)$ responden, tingkat pendidikan D3 sebanyak $3(7.3 \%)$, dan responden penelitian paling sedikit berada pada tingkat pendidikan SMP sebanyak $2(4.9 \%)$ responden.

Berdasarkan hasil analisis univariat karakteistik responden menurut hasil kuesioner pengetahuan ibu menjelaskan bahwa kateori yang menjawab baik sebanyak $8(19.5 \%)$ responden, kategori yang menjawab cukup sebanyak 17 $(41.5 \%)$ responden dan kategori yang menjawab kurang sebanyak 16 (39.0\%) responden. Dari penilaian kuesioner pengetahuan lbu di atas dapat dikatakan bahwa pengetahuan ibu wilayah kerja Puskesmas Kawangkoan Kabupaten Minahasa masih sangat belum memadai.

Hasil penelitian ini diketahui bahwa tingkat pemberian ASI eksklusif dari 41 responden sebanyak $61 \%$ yang tidak memberikan ASI Eksklusif, sedangkan $39 \%$ yang memberikan ASI Ekslusif. Hasil ini menggambarkan bahwa responden kurang memberikan ASI Eksklusif yang baik. 
Tabel 1. Analisis uji chi square pada pemberian ASI eklusif dengan kejadian Stunting

\begin{tabular}{|c|c|c|c|c|c|c|c|c|c|}
\hline \multirow{3}{*}{$\begin{array}{l}\text { Pemberian ASI } \\
\text { eksklusif }\end{array}$} & \multicolumn{6}{|c|}{ Status Gizi } & \multirow{2}{*}{\multicolumn{2}{|c|}{ Total }} & \multirow{2}{*}{ Chi square } \\
\hline & \multicolumn{2}{|c|}{ Normal } & \multicolumn{2}{|c|}{ Pendek } & \multicolumn{2}{|c|}{$\begin{array}{l}\text { Sangat } \\
\text { Pendek }\end{array}$} & & & \\
\hline & $\mathrm{n}$ & $\%$ & $\mathrm{~N}$ & $\%$ & $\mathrm{n}$ & $\%$ & $\mathrm{n}$ & $\%$ & $p$-value \\
\hline & 12 & 29.2 & 1 & 2.5 & 3 & 7.2 & 16 & 38.9 & \\
\hline & & & & & & & & & 0.02 \\
\hline & 7 & 17.1 & 8 & 19.5 & 10 & 24.5 & 25 & 61.1 & \\
\hline Total & 19 & 46.3 & 9 & 22 & 13 & 31.7 & 41 & 100 & \\
\hline
\end{tabular}

Dari tabel di atas diperlihatkan bahwa sampel yang diberikan ASI eksklusif dengan status gizi normal sebanyak 12 orang (29.2 \% ), dan pemberian ASI ekslusif kurang dengan status gizi sangat pendek yaitu 13 orang ( $31.7 \%$ ). Dari uji statistik diperoleh nilai $p=0.02$, maka Ho di tolak dan $\mathrm{H} 1$ diterima berarti terdapat hubungan yang bermakna pemberian ASI eksklusif.

\section{PEMBAHASAN}

Berdasarkan hasil penelitian menunjukkan bahwa ada hubungan antara pengetahuan Ibu dengan kejadian stunting di wilayah kerja Puskesmas Kawangkoan Kabupaten Minahasa dengan nilai $p$ value sebesar 0,01. Berdasarkan hasil penelitan menunjukkan bahwa sebagian responden yang memiliki status gizi normal sebanyak $7(17 \%)$ responden, dan sebagian responden yang memiliki status gizi kurang sebanyak $6(14.6 \%)$ responden.

Hasil penelitian ini sejalan dengan teori yang menyatakan bahwa pengetahuan atau kognitif merupakan domain yang sangat penting dalam membentuk tindakan seseorang. Dari pengalaman dan penelitian terbukti bahwa perilaku yang didasari oleh pengetahuan lebih langgeng dari pada perilaku yang tidak didasari oleh pengetahuan (Soekidjo Notoatmodjo, 2003). Penelitian terdahulu (Nining Yuliani Rohmatun, 2014) menyatakan bahwa pengetahuan Ibu terdapat hubungan yang signifikan dengan kejadian stunting pada balita.

Berdasarkan hasil penelitian menunjukkan bahwa ada hubungan tetapi tidak signifikan antara pemberian ASI Eksklusif dengan kejadian stunting di wilayah kerja Puskesmas Kawangkoan Kabupaten Minahasa dengan nilai $p$ value sebesar 0.02. Berdasarkan hasil Penelitian menunjukkan bahwa sebagian responden yang memiliki status gizi normal sebanyak 12 (29.2\%) responden dan sebagian responden yang memiliki status gizi kurang sebanyak $9(22 \%)$ responden.

Hasil penelitian diketahui bahwa sebagian besar responden memberikan ASI Eksklusifnya belum memadai pada balita. Hal ini menunjukkan bahwa capaian ASI eksklusif di tempat penelitian belum melebihi target nasional yang diharapkan yaitu sebesar 80\% (DepKes RI,2015). ASI Eksklusif menurut Peraturan Pemerintah Republik Indonesia Nomor 33 tahun 2012 tentang Pemberian Air Susu Ibu Eksklusif adalah pemberian Air Susu Ibu (ASI) tanpa menambahkan dan atau mengganti dengan makanan atau minuman lain yang diberikankepada bayi sejak baru dilahirkan selama 6 bulan. (Kemenkes R.I,2012). 
Pemberian ASI Eksklusif memberikan berbagai manfaat untuk Ibu dan bayi dimana ASI merupakan makanan alamiah yang baik untuk bayi, praktis, ekonomis, mudah dicerna, memiliki komposisi zat gizi yang ideal sesuai dengan kebutuhan dan kemampuan pencernaan bayi dan ASI mendukung pertumbuhan bayi terutama tinggi badan karena kalsium ASI lebih efisien dibanding susu pengganti ASI, (Prasetyono,2009).

Hasil penelitian menunjukkan sebanyak $13(31.7 \%)$ responden status gizi kurang karena tidak memberikan ASI Eksklusif, hal ini dapat terjadi karena kurangnya pengetahuan ibu tentang ASI Eksklusif yang dapat dikarenakan pendidikan ibu yang sangat rendah. Hal ini sesuai dengan hasil hasil penelitian sebelumnya bahwa tidak diberikanya ASI Eksklusif pada bayi dipengaruhi oleh beberapa faktor sesuai dengan penelitian yang dilakukan Setyawati (2012) mengungkapkan terdapat hubungan bermakna antara tingkat pengetahuan lbu tentang ASI Eksklusif dengan pemberian ASI Eksklusif di Desa Tjuk Kecamatan Getasan Kabupaten Semarang. Hal ini didukung penelitian Arifin (2012) dan (Sri Indrawati, 2017) yang meneliti faktor faktor yang paling nyata menyebkan kegagalan pemberian ASI Eksklusif adalah faktor pengetahuan,didapat alasan mengapa ibu tidak memberikan ASI Eksklusif kepada bayinya adalah sebagian besar yaitu $51,35 \%$ karena Ibu tidak mengetahui tentang pemberian ASI Eksklusif ,18,92\% karena Ibu bekerja,16,22\% karena ASI tidak keluar dan 13,51\% Ibu merasa bayinya tidak kenyang jika hanya diberi ASI.

\section{KESIMPULAN}

Terdapat hubungan yang bermakna antara pengetahuan ibu dengan kejadian stunting pada balita 2-5 tahun di wilayah kerja Puskesmas Kawangkoan Kabupaten Minahasa $(p=0.01)$. Demikian pula terdapat hubungan yang bermakna antara pemberian ASI eksklusif dengan kejadian stunting pada balita 2-5 tahun di wilayah kerja Puskesmas Kawangkoan Kabupaten Minahasa ( $p=0.02)$.

Berdasarkan kesimpulan penelitian, maka dapat disarankan kepada di wilayah kerja Puskesmas Kawangkoan Kabupaten Minahasa hendaknya lebih ditingkatkan sosialisasi tentang pengetahuan Gizi dan Pemberian ASI ekslusif terlebih khusus terhadap para ibu ibu. Praktek pemberian ASI yang baik berpengaruh bagi pertumbuhan dan perkembangan bayi dan balita hendaknya terus di tingkatkan sehingga diharapkan dapat meningktakan derajat kesehtan terutama menurunkan angka status gizi stunting di wilayah kerja Puskesmas Kawangkoan Kabupaten Minahasa. Petugas kesehatan memberikan motivasi pada ibu untuk terus memberikan ASI Eksklusif karena dengan pemberian ASI eksklusif dapat meningkatkan kekebalan tubuh bayi serta meningkatkan kecerdasan bayi

\section{DAFTAR PUSTAKA}

Aries. (2012). Hubungan Karakteristik Ibu dan Lama Pemberian ASI Eksklusif dengan Penyakit Infeksi dan Status Gizi Bayi Usia 1-6 bulan di Wilayah Kerja Puskesmas Bugangan Kecamatan Semarang. Timur.http:// eprints. Undip. ac.id/ 26158/1/52_Aries_G2C204105.doc_A.pdf

Fikawati, Sandra. (2015). Gizi Ibu dan Bayi. Jakarta: Rajawali Pers.

Notoadmodjo, S. (2007). Ilmu Perilaku Kesehatan. Jakarta: Rineka Cipta.

Notoadmodjo, S. (2010). Metodologi Penelitian Kesehatan. Jakarta: Rineka Cipta.

Onetusfifsi Putra. (2015). Pengaruh BBLR terhadap Kejadian Stunting pada Anak Usia 12 - 60 Bulan di Wilayah Kerja Puskesmas Pauh pada Tahun 2015.

Puskesmas Kawangkoan. (2018). Data Penanganan Kemiskinan dan Stunting Kabupaten Minahasa. 
Ramayulis, Rita. (2018). Stop Stunting dengan Konseling Gizi. Jakarta: Penebar Plust.

Rahmayana. (2014). Hubungan Pola Asuh Ibu dengan Kejadian Stunting Anak Usia 24-59 Bulan di Posyandu Asoka II Wilayah Pesisir Kelurahan Barombong Kecamatan Tamalate Kota Makassar Tahun 2014.

Ratnaningsih, Anastasia. (2017). Ibu Pintar Asuh Anak Cetakan I. Yogyakarta: Cemerlang Publishing.

Rikesdas. (2013). Prevalensi Balita Stunting. http://www.library.upnvj.ac.id. Diunduh tanggal 01 Mei 2018.

Roesli, Utami. (2005). Mengenal ASI Eksklusif. Jakarta: Trubus Agriwidya.

Mitra. (2015). Permasalahan Anak Stunting Dan Intervensi Untuk Mencegah Terjadinya Stunting. Jurnal Kesehatan Komunitas, No. Vol.2, Mei.

Unicef Indonesia. (2012). Ringkasan Kajian Gizi Ibu dan Anak. Jakarta.

World Health Organization. (2010). 10 Facts on Breast Feeding. http://www.who.int/features/factfiles/breastfeeding/facts/en/index4.html.

Sri Indrawati, Warsiti. (2016). Jurnal Hubungan Pemberian ASI Ekklusif dengan Kejadian Stunting Pada Anak Usia 2-3 Tahun di Desa Karangrejek Wonosari Gunungkidul.

Watania Tasya, Nelly Mayulu, Shirley E.S.Kawengian. (2016). Jurnal e-Biomedik, Volume 4, Nomor 2, Juli.. 